\title{
Non-Parametric Test Analysis for the Questionnaire Investigation on the High School Teachers' Work Load
}

\author{
Yasuo Ishii ${ }^{1}$, Daisuke Takeyasu ${ }^{2}$, Tatsuya Oyanagi ${ }^{3} \&$ Kazuhiro Takeyasu $^{4}$ \\ ${ }^{1}$ Yamato University, Japan \\ ${ }^{2}$ The Open University of Japan, Japan \\ ${ }^{3}$ Hachinohe Gakuin University, Japan \\ ${ }^{4}$ Tokoha University, Japan \\ Correspondence: Kazuhiro Takeyasu, Tokoha University, Japan.
}

Received: July 9, 2018

doi:10.5430/ijba.v9n5p33
Accepted: July 29, 2018

URL: https://doi.org/10.5430/ijba.v9n5p33

\begin{abstract}
High School teachers in Japan are sending very busy days on their daily works including teaching, support for the club activities and deskwork. Among them, they share a lot of time for managing the club actives of students compared with other countries. In that area, professionals can make instruction much better than teachers for the special sports like Judo and Kendo (Japanese fencing) etc. School Social Worker can coordinate the professionals out of school and can help teachers by decreasing their burden on that area. There are few related papers concerning the support of club activities by utilizing the professionals outside. In this paper, a questionnaire investigation is executed to the five High Schools at Miyagi Prefecture in Japan in order to clarify their current condition and their consciousness, and to seek the possibility of utilizing school social worker for their support. Fundamental statistical analysis and Non-Parametric Test Analysis are performed. As for Q2"Consciousness for the daily works" and its related analysis, Null Hypotheses were rejected for 6 cases out of 60. As for Q3"Consciousness for guiding the club activities" and its related analysis, Null Hypotheses were rejected for 5 cases out of 48 . Various cases should be investigated here after.
\end{abstract}

Keywords: high school teacher, non-parametric test, school social worker

\section{Introduction}

Teachers at High school / Junior High School in Japan are sending very busy days in general on their daily works including teaching, support for the club activities and deskwork. Among them, they share a lot of time for managing the club actives of students compared with other countries. In particular, it takes time to manage the club activities for sports. In that area, professionals can make instruction much better than teachers for the special sports like Judo and Kendo (Japanese fencing) etc. School Social Worker can coordinate the professionals out of school and can help teachers by decreasing their burden on that area.

There are many researches made on School Social Workers' function. For example, H. Konyuba (2011) analyzed the teacher's sparing time for club activities and pointed out that there is a difference between the sports club and the culture club. K.Yonekawa (2011) discussed the mental health support by school social worker. M.S.Kelly et al. (2010) made School Social work survey and derived instructive insight.

OECD (Organization for Economic Co-operation and Development) has released the investigation report of "Teaching and Learning International Survey (TALIS)" on June 25/2014. It is reported that the teacher's total working hours for a week in Japan were the most among 33 countries. Main data are as follows.

/Teacher's total working hours for a week in Japan: 53.9 (Average: 38.3)

/ Teacher's working hours of support for the club activities for a week in Japan: 7.7(Average: 2.1)

/Teacher's working hours of deskwork for a week in Japan: 5.5 (Average: 2.9)

/Teacher's teaching hours for a week in Japan: 17.7 (Average: 19.3)

Teacher's working hours of support for the club activities were nearly triple, and those of deskwork double compared 
with the average, while the teaching hours were less than those of the average. They are too busy for the support of the club activities and deskwork, which causes bad influence on their teaching activities.

Although there are some related papers as these, but there are few related papers concerning the support of club activities by utilizing the professionals outside especially in the Japanese case.

In this paper, a questionnaire investigation is executed to the five High Schools at Miyagi Prefecture in Japan in order to clarify their current condition and their consciousness, and to seek the possibility of utilizing school social worker for their support. Fundamental statistical analysis and Non-Parametric Test Analysis are performed. Some interesting results were obtained.

The rest of the paper is organized as follows. Outline of questionnaire investigation is stated in section 2 . Non-Parametric Test Analysis is conducted in section 3 which is followed by the Remarks of section 4.

\section{Outline and the Basic Statistical Results of the Questionnaire Research}

\subsection{Outline of the Questionnaire Research}

We make a questionnaire investigation for the Support of High School Teachers by the School Social Worker. The outline of questionnaire research is as follows. Questionnaire sheet is attached in Appendix.

(1) Scope of investigation

(2) Period

(3) Method

(4) Collection
: High School Teacher, 5 High Schools in Miyagi Prefecture, Japan

: August October 2015

Leave until called for

: Number of distribution 309

Number of collection 167(collection rate 54.0\%)

Valid answer 167

\subsection{Basic Statistical Results}

Now, we show the main summary results by single variable.

2.2.1 Characteristics of Answers (Q4)

(1) $\operatorname{Sex}(\mathrm{Q} 4-1)$

Male: $65.9 \%$

Female: $34.1 \%$

(2) Age (Q4-2)

20 29: $23.2 \%$

30 39: $24.4 \%$

40 49: $29.3 \%$

50 59: $18.9 \%$

More than 60: $4.3 \%$

(3) Position (Q4-3)

Deputy Principal: $0.6 \%$

A person in charge of educational affairs: $13.3 \%$

Teacher: $58.4 \%$

Lecturer: $22.9 \%$

Assistant: $1.2 \%$

Miscellaneous: $3.6 \%$

(4) Experience as a teacher (Q4-4)

More than 10 years consists of $60.7 \%$.

(5) How many years are you working for the present school?

$5 \sim 9$ years $(22.3 \%)$ and more than 10 years $(60.7 \%)$ consist of $80.3 \%$. 


\subsubsection{Club Activities}

(1) Sports Club (Q 1-2-1)

Large part one is Soccer (9.01\%), Baseball (7.21\%), Volleyball (7.21\%) and Table Tennis (7.21\%).

(2) Culture Club (Q1-2-2)

Main items are as follows.

/Broadcast Department: 6.15\%, /Literature: 4.62\%, /Brass ensemble: 4.62\%, /Instrumental music: 4.62\%/, Shogi(Japanese chess): $4.62 \%$.

(3) How about the sort of job? (Q1-2-2-3)

/Adviser: 72.1\%, /Deputy Adviser: 20.6\%, Miscellaneous: 7.3\%

Adviser holds the majority.

(4) Is the club strong enough to participate in the national sports match? (Q1-2-2-4)

Nearly $1 / 4$ of them are the strong teams to participate in the national sports match.

(5) Is the club activity active? (Q1-2-2-5)

More than half of them have selected "Yes".

(6) How long a time do you spare for the club activity (Include moving time) (Q1-2-2-6)

Up to 60 hours in month is nearly half and up to 90 hours reaches nearly $3 / 4$ in the total.

2.2.3 Consciousness for the Daily Works (Q2)

(1) Feel it burden to teach (Q2-1)

Nearly $16 \%$ of the teachers feel it burden to teach.

(2) Feel it burden to prepare for teaching (Q2-2)

Nearly $1 / 4$ of the teachers feel it burden to prepare for teaching.

(3) Feel it burden to instruct for learning (Q2-3)

Nearly $13 \%$ of the teachers feel it burden to instruct for learning.

(4) Feel it burden to handle the students' performance (Q2-4)

Nearly $1 / 4$ of the teachers feel it burden to handle the students' performance.

(5) Feel it burden to guide students (Q2-5)

Nearly $40 \%$ of the teachers feel it burden to guide students.

(6) Feel it burden to guide club activities (Q2-6)

Nearly $1 / 3$ of the teachers feel it burden to guide club activities.

(7) Feel it burden to manage the class (Q2-8)

Nearly $1 / 5$ of the teachers feel it burden to manage the class.

(8) Feel it burden to deal with meeting, advance arrangement (Q2-9)

Nearly $23 \%$ of the teachers feel it burden to deal with meeting, advance arrangement.

(9) Feel it burden to deal with parents (Q2-10)

Nearly $23 \%$ of the teachers feel it burden to deal with parents.

2.2.4 Consciousness for Guiding the Club Activities (Q3)

(1) Worthwhile to guide club activities (Q3-1)

Positive attitude to this theme can be seen (52\%).

(2) It is better for the professionals to guide club activities (Q3-2)

Strong positive attitude to this theme can be confirmed (79\%).

(3) I do not know the club field precisely that I take charge of (Q3-3)

Rather many teachers (31\%) feel anxiety for their expertise in their club field. 
(4) Quite tired because of the activity on holiday (Q3-5)

Nearly $40 \%$ of them feel tired because of the club activity on holiday.

(5) Have a hard time for the technical guidance (Q3-6)

Nearly $31 \%$ of them have a hard time for the technical guidance.

(6) Have a hard time for the mental guidance (Q3-7)

Nearly $1 / 3$ of them have a hard time for the mental guidance.

(7) Want to have a person to consult with in guiding club activities (Q3-8)

Nearly $41 \%$ of them want to have a person to consult with in guiding club activities.

\section{Non-Parametric Test}

Non-Parametric Test is executed concerning Q2 "Consciousness for the daily works" and Q3 "Consciousness for guiding the club activities". Cross tabulation is calculated for the items of Q4-1 "Sex", Q4-2 "Age", Q4-3 "Position", Q4-4 "Experience as a teacher", Q4-5 "How many years are you working for the present school?", Q4-7 "Marriage" etc.

Significance probability is calculated as Table 1 and Table 2 for each case. Hatched parts in Table 1 and Table 2 are the Null Hypothesis rejected cases under 5\% significance level.

As Q2 and Q3 are ordinal scale, Kruskal Wallis Test is examined, which reflects order information.

Table 1. Q2 "Consciousness for the daily works"

\begin{tabular}{|c|c|c|c|c|c|c|c|c|c|c|}
\hline & $\begin{array}{l}\text { Burden } \\
\text { for } \\
\text { teaching }\end{array}$ & $\begin{array}{l}\text { Burden } \\
\text { for } \\
\text { preparing } \\
\text { teaching }\end{array}$ & $\begin{array}{l}\text { Burden } \\
\text { for } \\
\text { instructi } \\
\text { ng } \\
\text { learning }\end{array}$ & $\begin{array}{l}\text { Burden for } \\
\text { handling } \\
\text { students' } \\
\text { performance }\end{array}$ & $\begin{array}{l}\text { Burden } \\
\text { for } \\
\text { guiding } \\
\text { students }\end{array}$ & $\begin{array}{l}\text { Burden for } \\
\text { guiding } \\
\text { club } \\
\text { activities }\end{array}$ & $\begin{array}{l}\text { Burden for } \\
\text { attending } \\
\text { conference }\end{array}$ & $\begin{array}{l}\text { Burden } \\
\text { for } \\
\text { managing } \\
\text { the class }\end{array}$ & $\begin{array}{l}\text { Burden } \\
\text { for } \\
\text { dealing } \\
\text { with } \\
\text { meeting }\end{array}$ & $\begin{array}{l}\text { Burden } \\
\text { for } \\
\text { dealing } \\
\text { with } \\
\text { parents }\end{array}$ \\
\hline Sex & 0.897 & 0.689 & 0.717 & 0.838 & 0.442 & 0.114 & 0.396 & 0.390 & 0.222 & 0.691 \\
\hline Age & 0.029 & 0.695 & 0.096 & 0.264 & 0.313 & 0.633 & 0.563 & 0.041 & 0.009 & 0.359 \\
\hline $\begin{array}{l}\text { Experience } \\
\text { years at the } \\
\text { present school }\end{array}$ & 0.407 & 0.663 & 0.407 & 0.568 & 0.233 & 0.773 & 0.101 & 0.043 & 0.251 & 0.006 \\
\hline
\end{tabular}

Table 2. Q3 "Consciousness for guiding the club activities"

\begin{tabular}{|c|c|c|c|c|c|c|c|c|}
\hline & $\begin{array}{c}\text { Feel } \\
\text { worthwh } \\
\text { ile }\end{array}$ & $\begin{array}{l}\text { Better for the } \\
\text { professionals } \\
\text { to guide club } \\
\text { activities }\end{array}$ & $\begin{array}{l}\text { Inexper } \\
\text { ience }\end{array}$ & $\begin{array}{c}\text { Cannot to } \\
\text { share time } \\
\text { to prepare } \\
\text { teaching }\end{array}$ & $\begin{array}{l}\text { Quite } \\
\text { tired on } \\
\text { holiday } \\
\text { activity }\end{array}$ & $\begin{array}{l}\text { Have a hard } \\
\text { time for the } \\
\text { technical } \\
\text { guidance }\end{array}$ & $\begin{array}{l}\text { Have a hard } \\
\text { time for the } \\
\text { mental } \\
\text { guidance }\end{array}$ & $\begin{array}{l}\text { Want the } \\
\text { person to } \\
\text { consult with }\end{array}$ \\
\hline Sex & 0.662 & 0.531 & 0.246 & 0.274 & 0.416 & 0.020 & 0.889 & 0.025 \\
\hline Age & 0.261 & 0.334 & 0.335 & 0.650 & 0.311 & 0.136 & 0.838 & 0.033 \\
\hline Position & 0.984 & 0.361 & 0.633 & 0.148 & 0.055 & 0.119 & 0.021 & 0.171 \\
\hline $\begin{array}{c}\text { Experience years } \\
\text { as a teacher }\end{array}$ & 0.129 & 0.674 & 0.269 & 0.113 & 0.629 & 0.624 & 0.668 & 0.022 \\
\hline $\begin{array}{c}\text { Experience years } \\
\text { at the present } \\
\text { school }\end{array}$ & 0.331 & 0.938 & 0.619 & 0.100 & 0.830 & 0.845 & 0.135 & 0.203 \\
\hline Marriage & 0.923 & 0.903 & 0.086 & 0.483 & 0.493 & 0.081 & 0.238 & 0.124 \\
\hline
\end{tabular}


Each case of hatched parts is considered hereafter in the following section.

\subsection{Age and Daily Works}

3.1.1 Age and the Burden for Teaching

Table 3. Age and the Burden for teaching

\begin{tabular}{|c|c|c|c|c|c|c|c|c|}
\hline & & \multicolumn{7}{|c|}{ 2-1 Burden for teaching } \\
\hline & & & $\begin{array}{c}\text { Think it very } \\
\text { much }\end{array}$ & $\begin{array}{l}\text { Slightly think } \\
\text { so }\end{array}$ & $\begin{array}{c}\text { Cannot say } \\
\text { either }\end{array}$ & $\begin{array}{l}\text { Slightly do not } \\
\text { think so }\end{array}$ & $\begin{array}{l}\text { Do not think } \\
\text { so }\end{array}$ & Total \\
\hline $4-2$ & Under & Frequency & 1 & 0 & 0 & 0 & 0 & 1 \\
\hline \multirow[t]{11}{*}{ Age } & 20 & $\%$ & 100.0 & .0 & .0 & .0 & .0 & 100.0 \\
\hline & $20-29$ & Frequency & 1 & 1 & 5 & 22 & 8 & 37 \\
\hline & & $\%$ & 2.7 & 2.7 & 13.5 & 59.5 & 21.6 & 100.0 \\
\hline & $30-39$ & Frequency & 0 & 5 & 5 & 20 & 10 & 40 \\
\hline & & $\%$ & .0 & 12.5 & 12.5 & 50.0 & 25.0 & 100.0 \\
\hline & $40-49$ & Frequency & 1 & 10 & 14 & 13 & 10 & 48 \\
\hline & & $\%$ & 2.1 & 20.8 & 29.2 & 27.1 & 20.8 & 100.0 \\
\hline & $50-59$ & Frequency & 1 & 4 & 10 & 9 & 6 & 30 \\
\hline & & $\%$ & 3.3 & 13.3 & 33.3 & 30.0 & 20.0 & 100.0 \\
\hline & More & Frequency & 1 & 1 & 1 & 4 & 0 & 7 \\
\hline & than 60 & $\%$ & 14.3 & 14.3 & 14.3 & 57.1 & .0 & 100.0 \\
\hline \multirow[t]{2}{*}{ Total } & & Frequency & 5 & 21 & 35 & 68 & 34 & 163 \\
\hline & & $\%$ & 3.1 & 12.9 & 21.5 & 41.7 & 20.9 & 100.0 \\
\hline
\end{tabular}

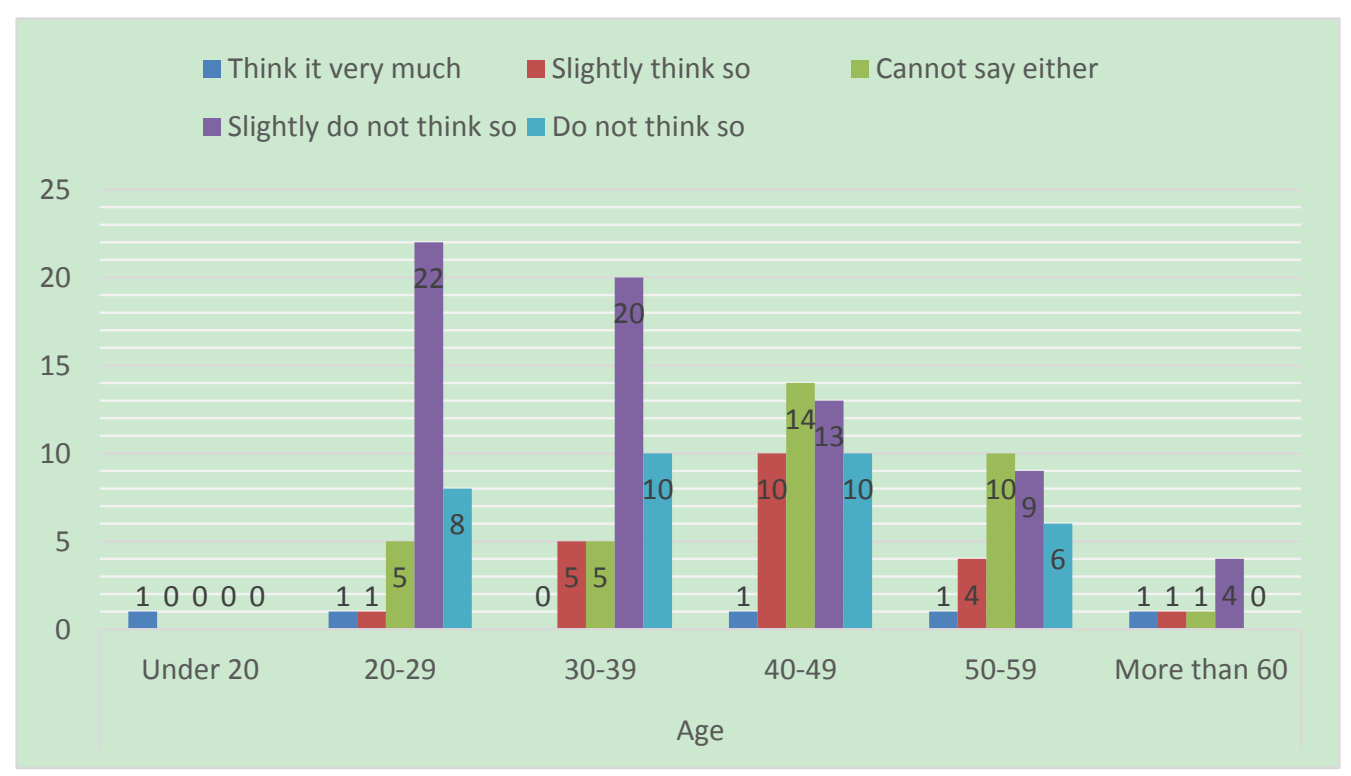

Figure 1. Age and the burden for teaching

Teachers of $40^{\text {th }}$ have a rather high burden feeling for teaching. They may hold many daily works. 


\subsubsection{Age and the Burden for Class Management}

Table 4. Age and the burden for class management

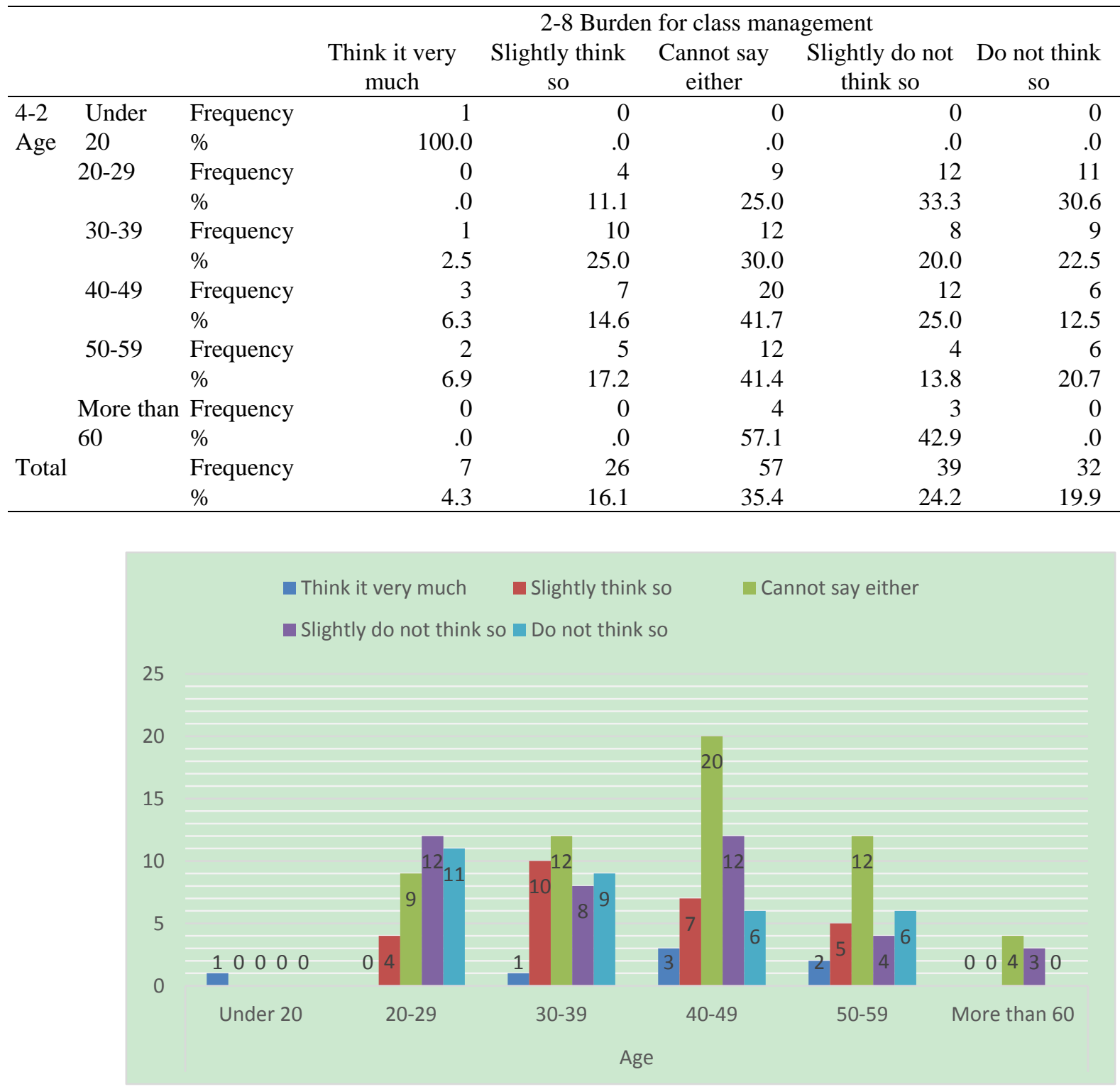

Figure 2. Age and the burden for class management

Teachers of $30^{\text {th }}$ and $40^{\text {th }}$ have a high burden feeling for class management. 


\subsubsection{Age and the Burden for Dealing With Meeting}

Table 5. Age and the burden for dealing with meeting

\begin{tabular}{|c|c|c|c|c|c|c|c|c|}
\hline & & & \multicolumn{5}{|c|}{ 2-9 Burden for dealing with meeting } & \multirow[b]{2}{*}{ Total } \\
\hline & & & $\begin{array}{l}\text { Think it very } \\
\text { much }\end{array}$ & $\begin{array}{l}\text { Slightly think } \\
\text { so }\end{array}$ & $\begin{array}{l}\text { Cannot say } \\
\text { either }\end{array}$ & $\begin{array}{l}\text { Slightly do } \\
\text { not think so }\end{array}$ & $\begin{array}{l}\text { Do not think } \\
\text { so }\end{array}$ & \\
\hline $4-2$ & Under & Frequency & 1 & 0 & 0 & 0 & 0 & 1 \\
\hline \multirow[t]{11}{*}{ Age } & 20 & $\%$ & 100.0 & .0 & .0 & 0 & .0 & 100.0 \\
\hline & $20-29$ & Frequency & 1 & 2 & 10 & 15 & 9 & 37 \\
\hline & & $\%$ & 2.7 & 5.4 & 27.0 & 40.5 & 24.3 & 100.0 \\
\hline & $30-39$ & Frequency & 3 & 7 & 13 & 9 & 8 & 40 \\
\hline & & $\%$ & 7.5 & 17.5 & 32.5 & 22.5 & 20.0 & 100.0 \\
\hline & $40-49$ & Frequency & 7 & 4 & 20 & 13 & 4 & 48 \\
\hline & & $\%$ & 14.6 & 8.3 & 41.7 & 27.1 & 8.3 & 100.0 \\
\hline & $50-59$ & Frequency & 3 & 7 & 10 & 7 & 3 & 30 \\
\hline & & $\%$ & 10.0 & 23.3 & 33.3 & 23.3 & 10.0 & 100.0 \\
\hline & More than & Frequency & 0 & 2 & 3 & 2 & 0 & 7 \\
\hline & 60 & $\%$ & .0 & 28.6 & 42.9 & 28.6 & .0 & 100.0 \\
\hline \multirow[t]{2}{*}{ Total } & & Frequency & 15 & 22 & 56 & 46 & 24 & 163 \\
\hline & & $\%$ & 9.2 & 13.5 & 34.4 & 28.2 & 14.7 & 100.0 \\
\hline
\end{tabular}

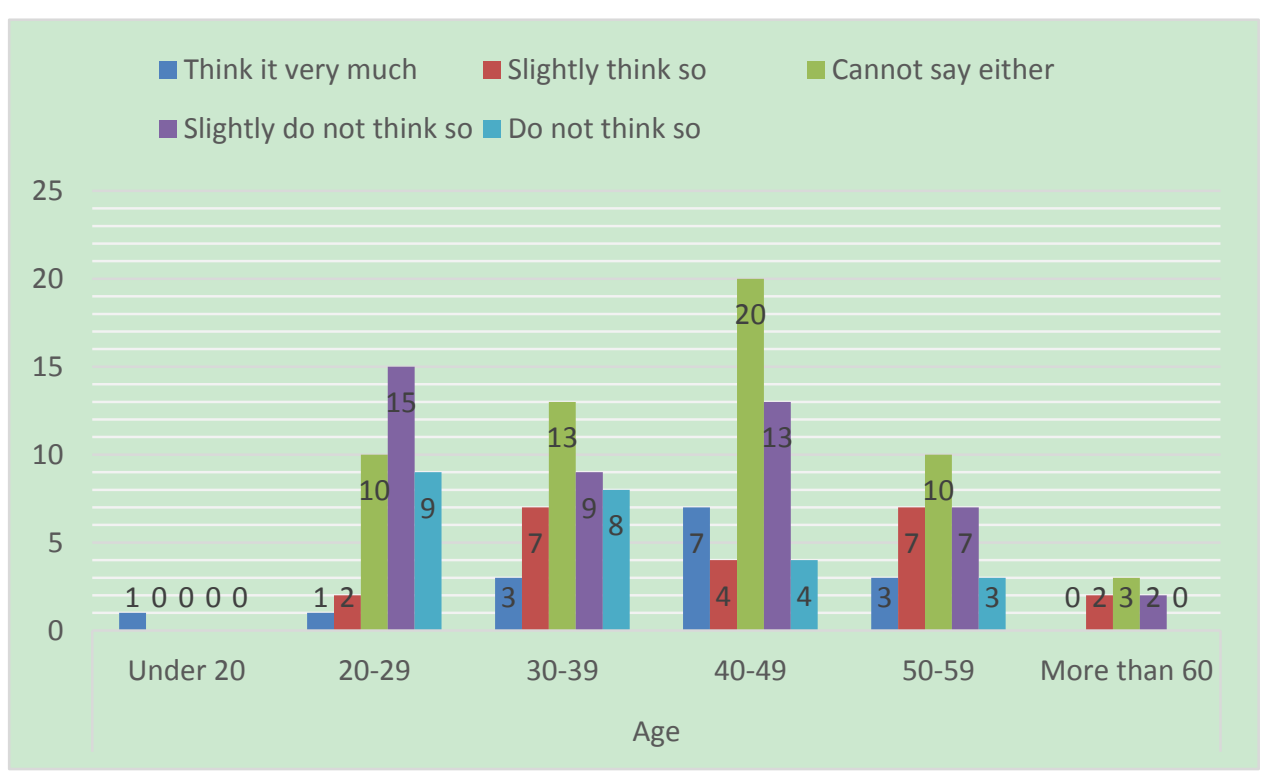

Figure 3. Age and the burden for dealing with meeting

Teachers of $30^{\text {th }}, 40^{\text {th }}$ and $50^{\text {th }}$ have a high burden feeling for dealing with meeting. 


\subsection{Position and Daily Works}

\subsubsection{Position and the Burden for Dealing With Parents}

Table 6. Position and the burden for dealing with parents

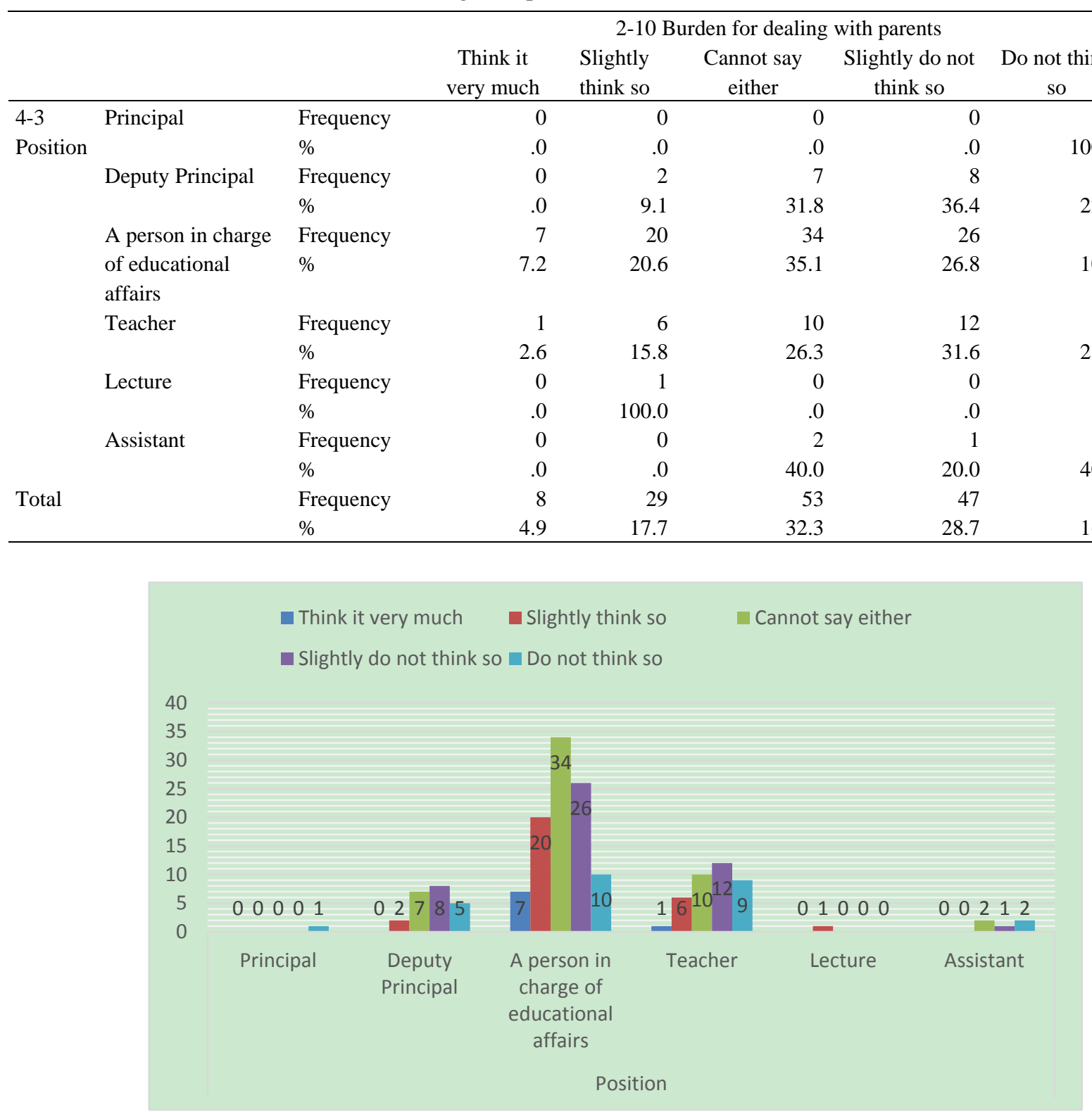

Figure 4. Position and the burden for dealing with parents

Position as a teacher feel it burden for dealing with parents. 


\subsection{Experience Years at the Present School and the Consciousness for the Daily Works}

3.3.1 Experience Years at the Present School and the Burden for Class Management

Table 7. Experience years at the present school and the burden for class management

\begin{tabular}{|c|c|c|c|c|c|c|c|c|}
\hline & & & & 2-8 Burde & $\mathrm{n}$ for class $\mathrm{m}$ & inagement & & Total \\
\hline & & & $\begin{array}{l}\text { Think it } \\
\text { very much }\end{array}$ & $\begin{array}{l}\text { Slightly } \\
\text { think so }\end{array}$ & $\begin{array}{l}\text { Cannot say } \\
\text { either }\end{array}$ & $\begin{array}{l}\text { Slightly do } \\
\text { not think so }\end{array}$ & $\begin{array}{l}\text { Do not } \\
\text { think so }\end{array}$ & \\
\hline $4-5$ & Within 1 & Frequency & 0 & 1 & 0 & 3 & 5 & 9 \\
\hline Experie & year & $\%$ & .0 & 11.1 & .0 & 33.3 & 55.6 & 100.0 \\
\hline nce & $1-2$ years & Frequency & 0 & 0 & 5 & 2 & 1 & 8 \\
\hline years at & & $\%$ & .0 & .0 & 62.5 & 25.0 & 12.5 & 100.0 \\
\hline & 3-4 Years & Frequency & 2 & 3 & 8 & 6 & 6 & 25 \\
\hline present & & $\%$ & 8.0 & 12.0 & 32.0 & 24.0 & 24.0 & 100.0 \\
\hline school & 5-9 years & Frequency & 0 & 7 & 10 & 14 & 6 & 37 \\
\hline & & $\%$ & .0 & 18.9 & 27.0 & 37.8 & 16.2 & 100.0 \\
\hline & 10 years & Frequency & 5 & 15 & 35 & 14 & 14 & 83 \\
\hline & more & $\%$ & 6.0 & 18.1 & 42.2 & 16.9 & 16.9 & 100.0 \\
\hline Total & & Frequency & 7 & 26 & 58 & 39 & 32 & 162 \\
\hline & & $\%$ & 4.3 & 16.0 & 35.8 & 24.1 & 19.8 & 100.0 \\
\hline
\end{tabular}

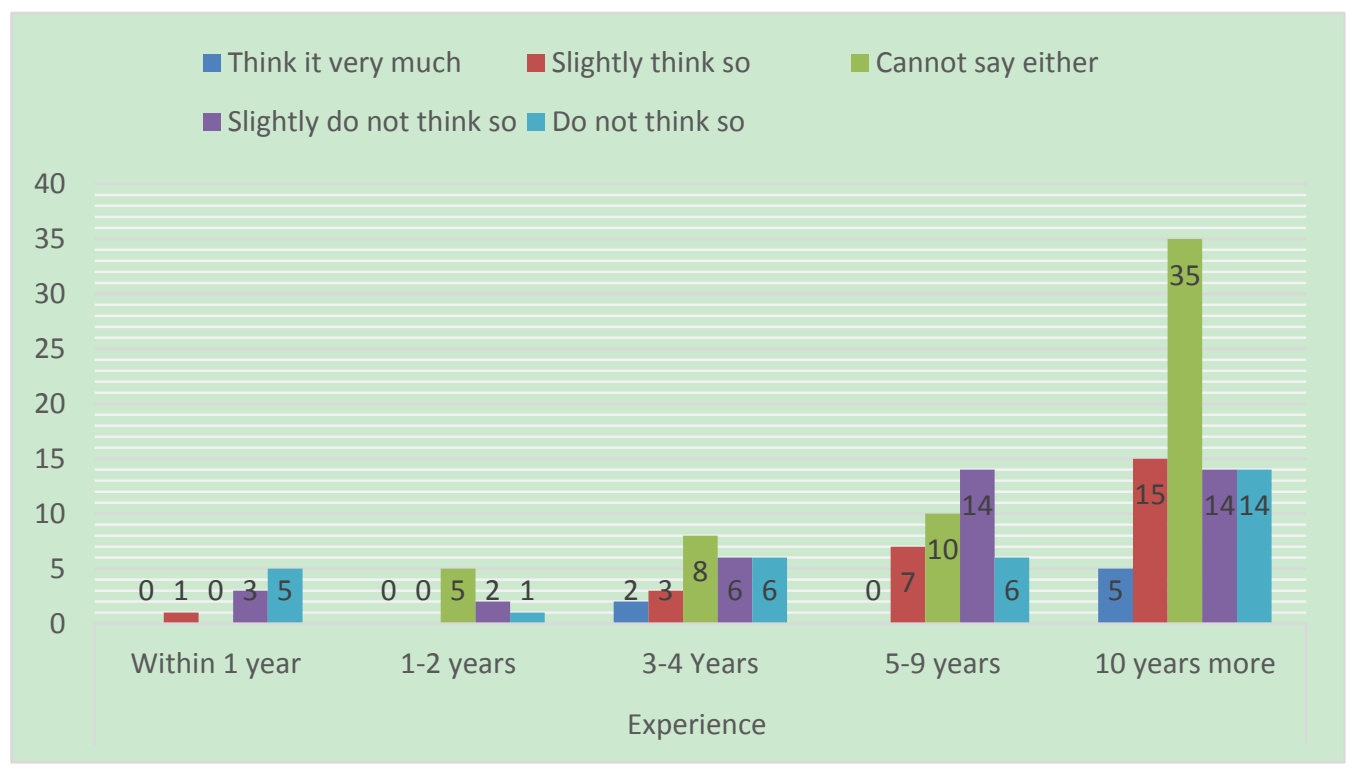

Figure 5. Experience years at the present school and the burden for class management

Veteran for more than 10 years feel it burden to manage the class. 


\subsubsection{Experience Years at the Present School and the Burden for Dealing With Parents}

Table 8. Experience years at the present school and the burden for dealing with parents

\begin{tabular}{|c|c|c|c|c|c|c|c|c|}
\hline$\%$ & & & \multicolumn{5}{|c|}{ 2-10 Burden for dealing with parents } & \multirow{2}{*}{ Total } \\
\hline & & & very mu & tnink so & CIIIIEI & 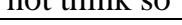 & tnink so & \\
\hline $4-5$ & Within 1 & Frequency & 0 & 0 & 1 & 2 & 7 & 10 \\
\hline Experi & year & $\%$ & .0 & .0 & 10.0 & 20.0 & 70.0 & 100.0 \\
\hline ence & $1-2$ years & Frequency & 0 & 2 & 2 & 3 & 1 & 8 \\
\hline years & & $\%$ & .0 & 25.0 & 25.0 & 37.5 & 12.5 & 100.0 \\
\hline at the & $3-4$ & Frequency & 2 & 4 & 7 & 10 & 2 & 25 \\
\hline present & Years & $\%$ & 8.0 & 16.0 & 28.0 & 40.0 & 8.0 & 100.0 \\
\hline school & $5-9$ years & Frequency & 2 & 8 & 10 & 9 & 8 & 37 \\
\hline & & $\%$ & 5.4 & 21.6 & 27.0 & 24.3 & 21.6 & 100.0 \\
\hline & 10 years & Frequency & 4 & 15 & 33 & 23 & 9 & 84 \\
\hline & more & $\%$ & 4.8 & 17.9 & 39.3 & 27.4 & 10.7 & 100.0 \\
\hline Total & & Frequency & 8 & 29 & 53 & 47 & 27 & 164 \\
\hline & & $\%$ & 4.9 & 17.7 & 32.3 & 28.7 & 16.5 & 100.0 \\
\hline
\end{tabular}

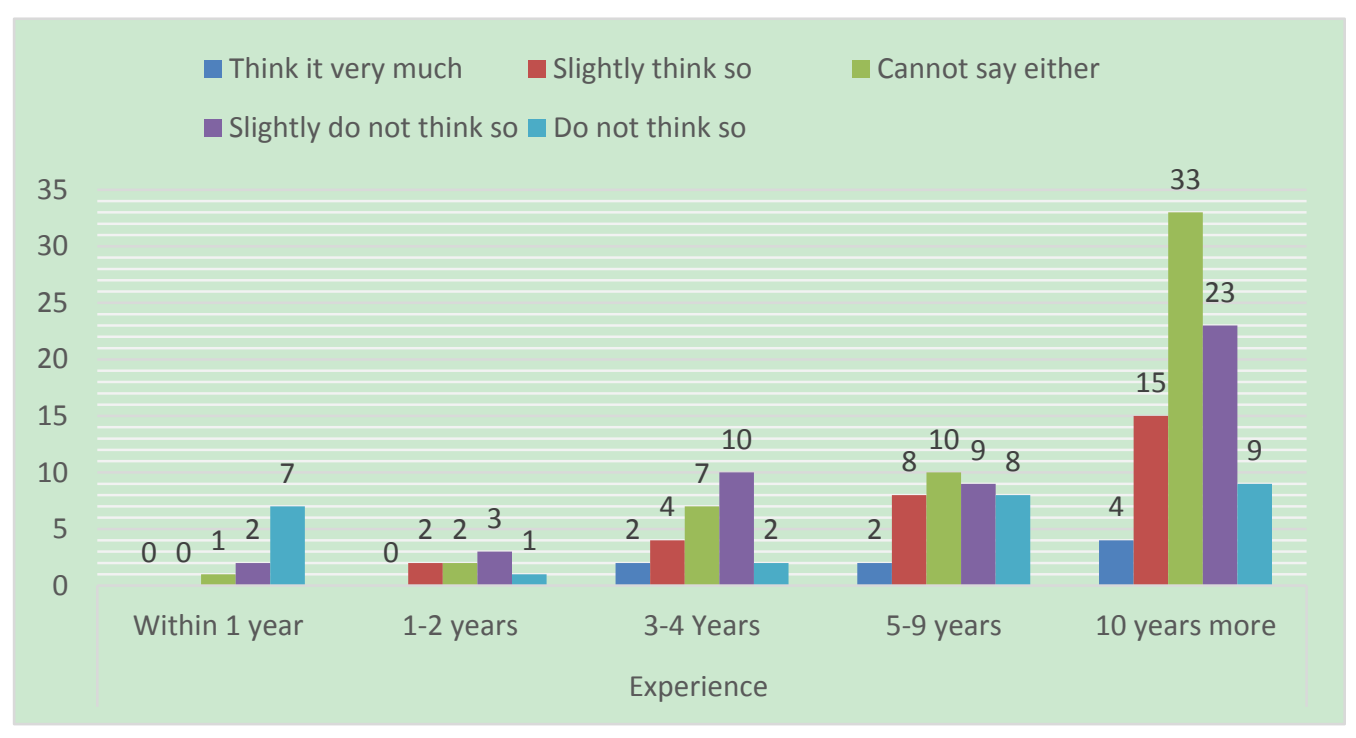

Figure 6. Experience years at the present school and the burden for dealing with parents

Teachers of experience years more than 5 years at the present school feel it burden to deal with parents.

\subsection{Sex and the Consciousness for Guiding the Club Activities}

3.4.1 Sex and the Burden for the Technical Guidance in the Club Activities

Table 9. Sex and burden for the technical guidance in the club activities

\begin{tabular}{|c|c|c|c|c|c|c|c|c|}
\hline & & & \multicolumn{5}{|c|}{ 3-6 Burden for the technical guidance in the club activities } & \multirow[t]{2}{*}{ Total } \\
\hline & & & $\begin{array}{c}\text { Think it very } \\
\text { much }\end{array}$ & $\begin{array}{l}\text { Slightly } \\
\text { think so }\end{array}$ & $\begin{array}{l}\text { Cannot say } \\
\text { either }\end{array}$ & $\begin{array}{l}\text { Slightly do } \\
\text { not think so }\end{array}$ & $\begin{array}{l}\text { Do not think } \\
\text { so }\end{array}$ & \\
\hline $4-1$ & Male & Frequency & 8 & 16 & 37 & 19 & 28 & 108 \\
\hline \multirow[t]{3}{*}{ Sex } & & $\%$ & 7.4 & 14.8 & 34.3 & 17.6 & 25.9 & 100.0 \\
\hline & Female & Frequency & 7 & 18 & 13 & 6 & 11 & 55 \\
\hline & & $\%$ & 12.7 & 32.7 & 23.6 & 10.9 & 20.0 & 100.0 \\
\hline \multirow[t]{2}{*}{ Total } & & Frequency & 15 & 34 & 50 & 25 & 39 & 163 \\
\hline & & $\%$ & 9.2 & 20.9 & 30.7 & 15.3 & 23.9 & 100.0 \\
\hline
\end{tabular}




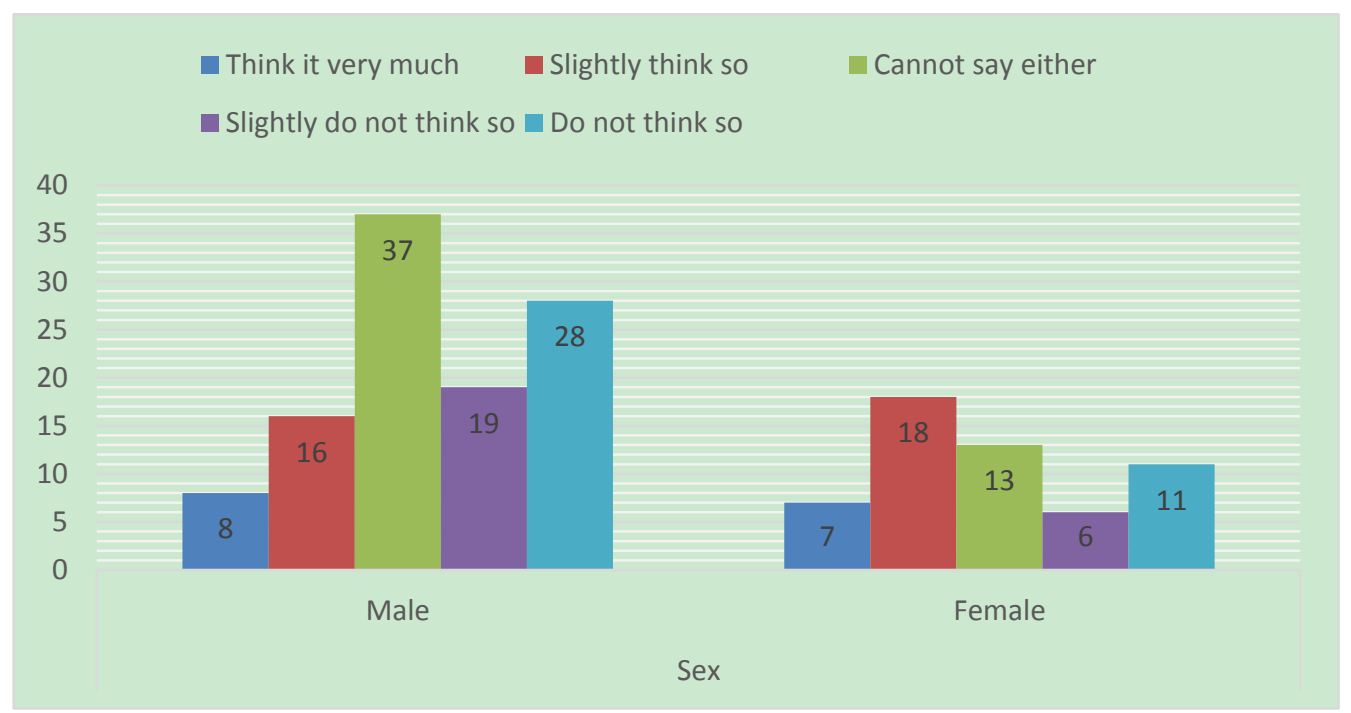

Figure 7. Sex and burden for the technical guidance in the club activities

Female feel more burden than male for the technical guidance in the club activities.

3.4.2 Sex and "Want the Person to Consult With in Guiding the Club Activities"

Table 10. Sex and "Want the person to consult with in guiding the club activities"

\begin{tabular}{|c|c|c|c|c|c|c|c|c|}
\hline & & & \multicolumn{5}{|c|}{ 3-8 Want the person to consult with in guiding the club activities } & \multirow[b]{2}{*}{ Total } \\
\hline & & & $\begin{array}{l}\text { Think it } \\
\text { very much }\end{array}$ & $\begin{array}{l}\text { Slightly } \\
\text { think so }\end{array}$ & $\begin{array}{c}\text { Cannot say } \\
\text { either }\end{array}$ & $\begin{array}{l}\text { Slightly do } \\
\text { not think so }\end{array}$ & $\begin{array}{l}\text { Do not } \\
\text { think so }\end{array}$ & \\
\hline $4-1$ & Male & Frequency & 18 & 19 & 37 & 16 & 18 & 108 \\
\hline \multirow[t]{3}{*}{ Sex } & & $\%$ & 16.7 & 17.6 & 34.3 & 14.8 & 16.7 & 100.0 \\
\hline & Female & Frequency & 12 & 18 & 16 & 5 & 5 & 56 \\
\hline & & $\%$ & 21.4 & 32.1 & 28.6 & 8.9 & 8.9 & 100.0 \\
\hline \multirow[t]{2}{*}{ Total } & & Frequency & 30 & 37 & 53 & 21 & 23 & 164 \\
\hline & & $\%$ & 18.3 & 22.6 & 32.3 & 12.8 & 14.0 & 100.0 \\
\hline
\end{tabular}

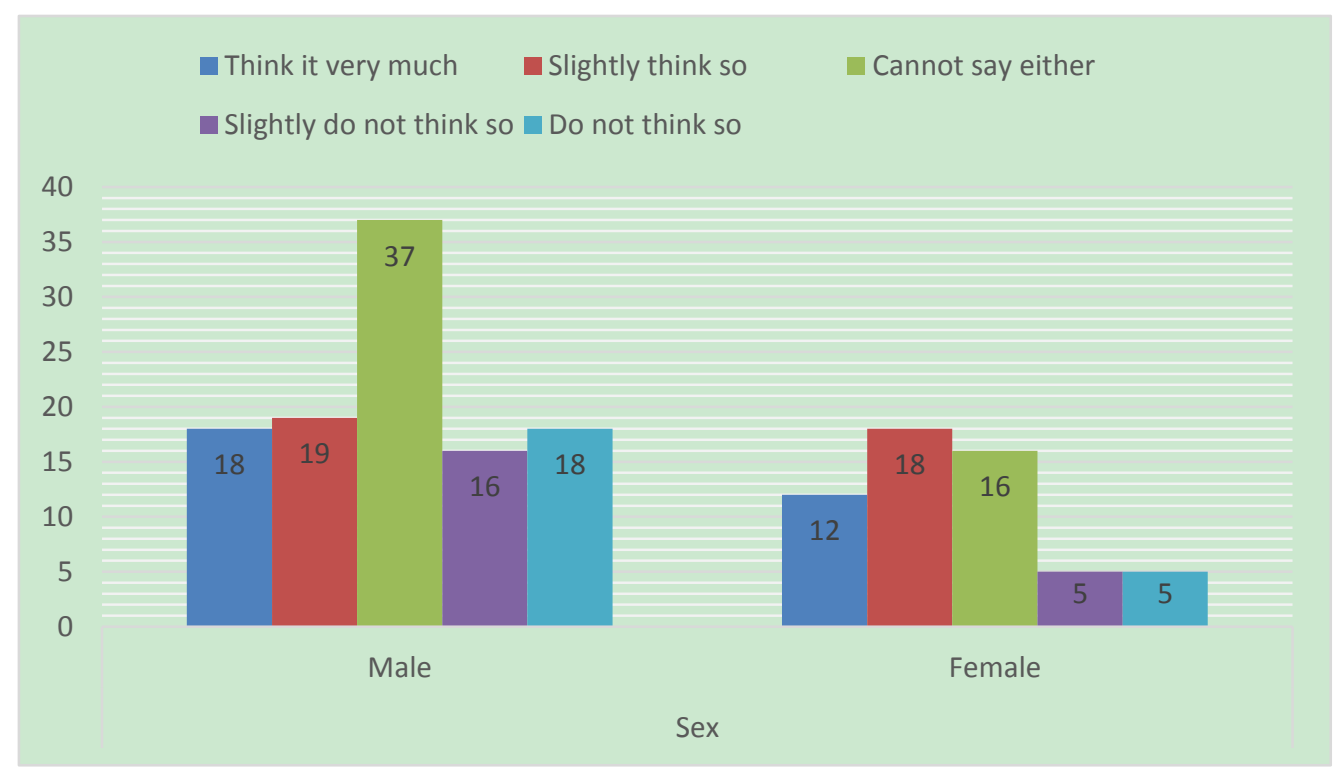

Figure 8. Sex and "Want the person to consult with in guiding the club activities" 
Female feels much more than male that she wants the person to consult with in guiding club activities.

3.5 Age and the Consciousness for Guiding the Club Activities

3.5.1 Age and "Want the Person to Consult With in Guiding the Club Activities"

Table 11. Age and "Want the person to consult with in guiding the club activities"

\begin{tabular}{|c|c|c|c|c|c|c|c|c|}
\hline & & & 3-8 Want the & person to co & nsult with in & guiding the $\mathrm{cl}$ & activities & Total \\
\hline & & & $\begin{array}{c}\text { Think it } \\
\text { very much }\end{array}$ & $\begin{array}{l}\text { Slightly } \\
\text { think so }\end{array}$ & $\begin{array}{c}\text { Cannot say } \\
\text { either }\end{array}$ & $\begin{array}{l}\text { Slightly do } \\
\text { not think so }\end{array}$ & $\begin{array}{l}\text { Do not } \\
\text { think so }\end{array}$ & \\
\hline $4-2$ & Under & Frequency & 0 & 0 & 1 & 0 & 0 & 1 \\
\hline Age & 20 & $\%$ & .0 & .0 & 100.0 & .0 & .0 & 100.0 \\
\hline & $20-29$ & Frequency & 8 & 9 & 13 & 6 & 2 & 38 \\
\hline & & $\%$ & 21.1 & 23.7 & 34.2 & 15.8 & 5.3 & 100.0 \\
\hline & $30-39$ & Frequency & 14 & 6 & 10 & 3 & 7 & 40 \\
\hline & & $\%$ & 35.0 & 15.0 & 25.0 & 7.5 & 17.5 & 100.0 \\
\hline & $40-49$ & Frequency & 8 & 15 & 15 & 4 & 6 & 48 \\
\hline & & $\%$ & 16.7 & 31.3 & 31.3 & 8.3 & 12.5 & 100.0 \\
\hline & $50-59$ & Frequency & 0 & 7 & 11 & 5 & 8 & 31 \\
\hline & & $\%$ & .0 & 22.6 & 35.5 & 16.1 & 25.8 & 100.0 \\
\hline & More & Frequency & 0 & 1 & 3 & 3 & 0 & 7 \\
\hline & than 60 & $\%$ & .0 & 14.3 & 42.9 & 42.9 & .0 & 100.0 \\
\hline Total & & Frequency & 30 & 38 & 53 & 21 & 23 & 165 \\
\hline & & $\%$ & 18.2 & 23.0 & 32.1 & 12.7 & 13.9 & 100.0 \\
\hline
\end{tabular}

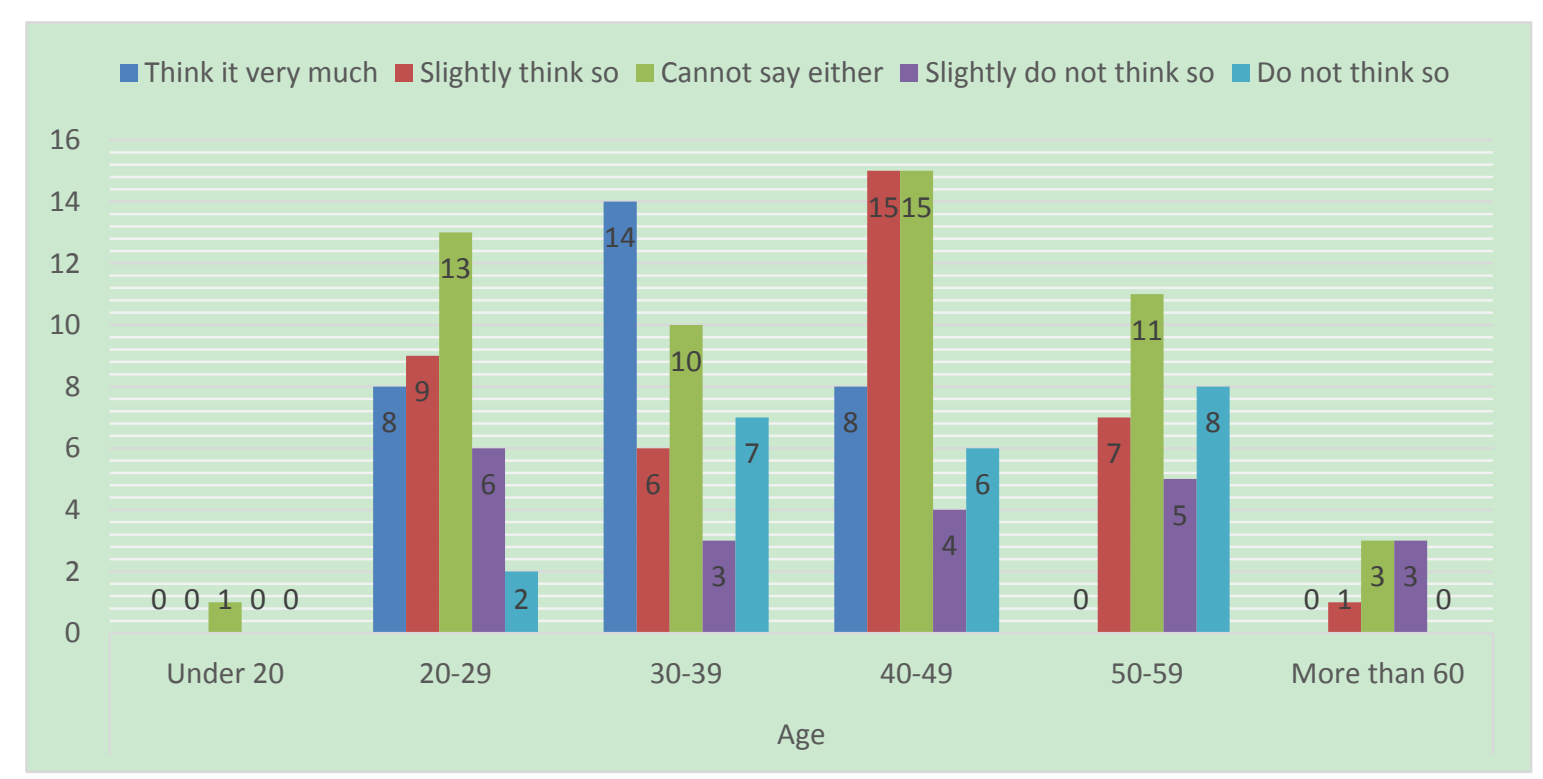

Figure 9. Age and "Want the person to consult with in guiding the club activities"

Rather young teachers of $20^{\text {th }}$ through $40^{\text {th }}$ want the person to consult with in guiding the club activities. 


\subsection{Position and the Consciousness for Guiding the Club Activities}

3.6.1 Position and the Burden for the Mental Guidance in the Club Activities

Table 12. Position and the Burden for the mental guidance in the club activities

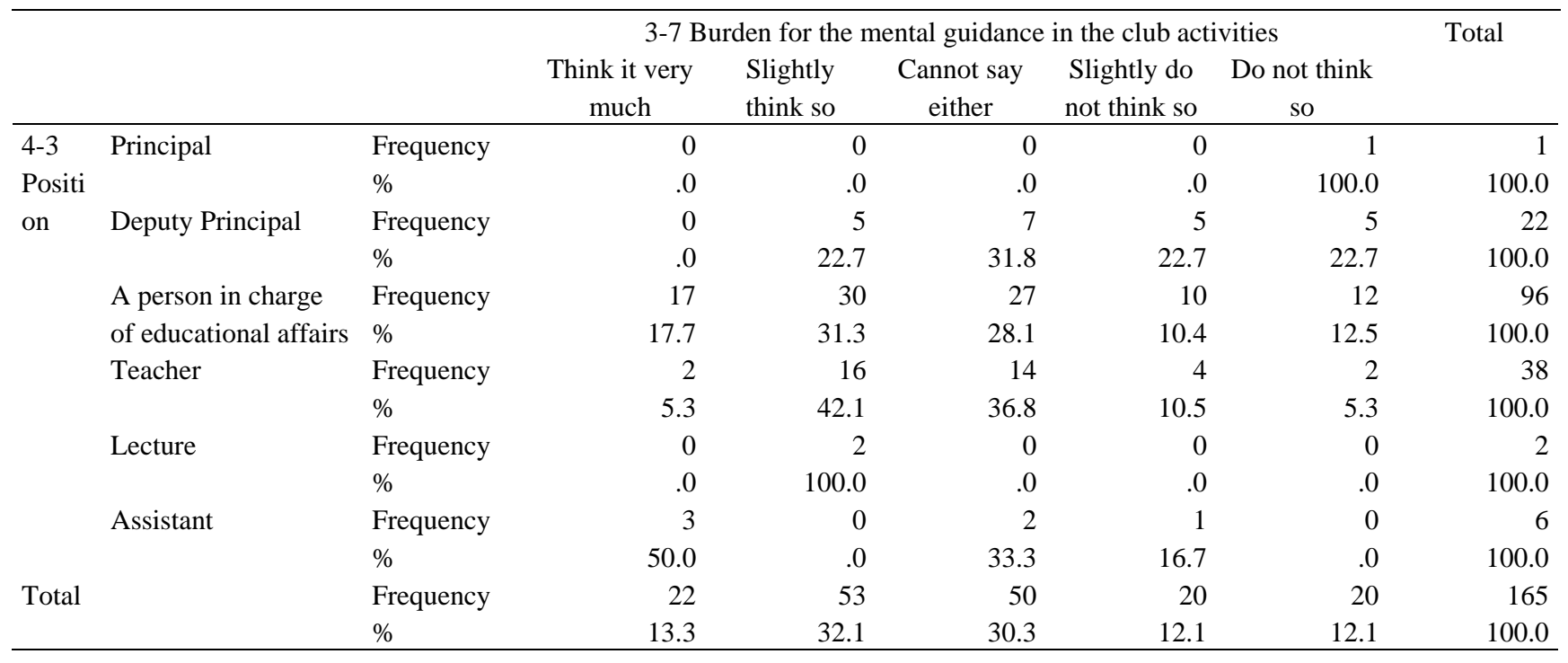

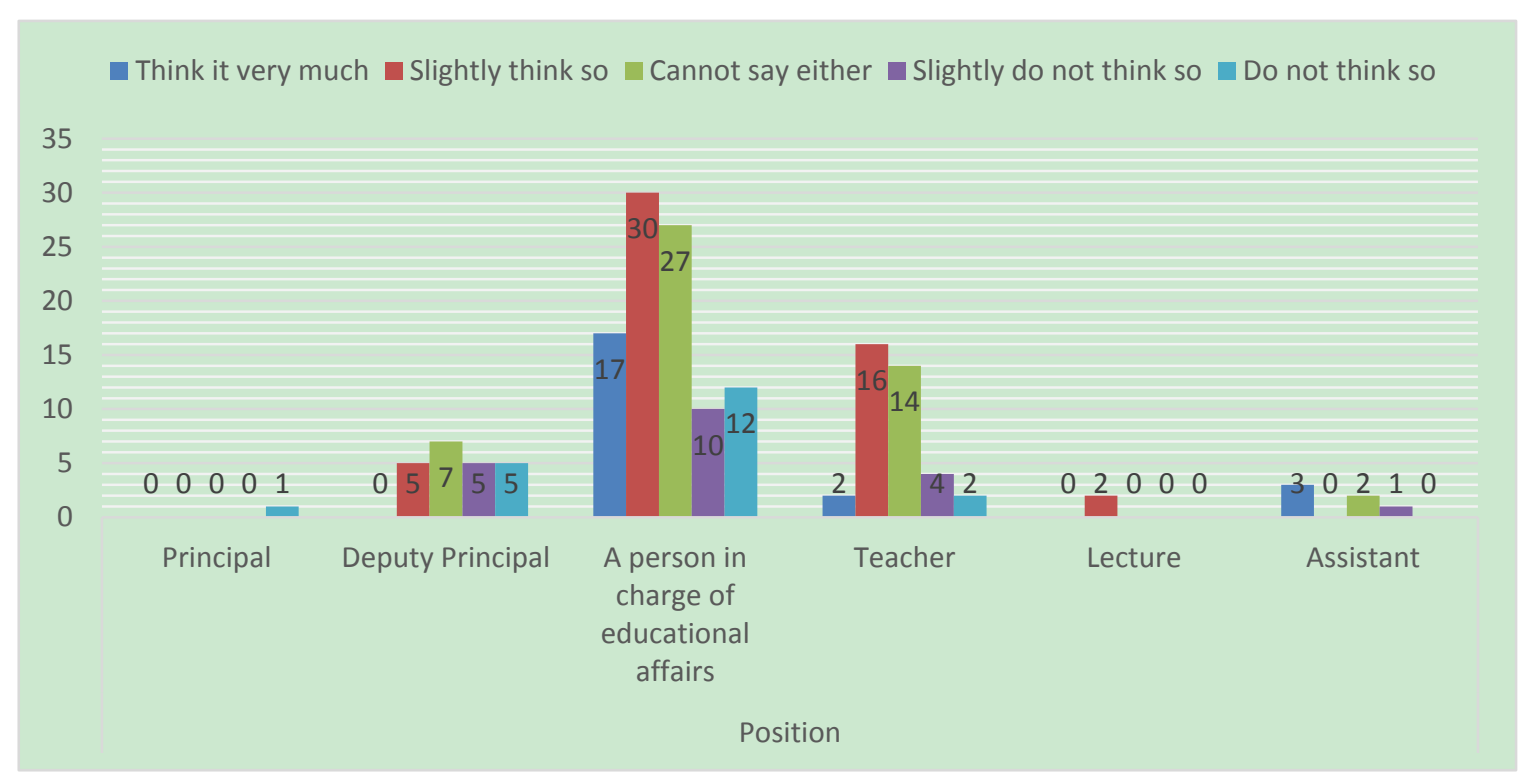

Figure 10. Position and the burden for the mental guidance in the club activities

Teachers and Lecturers, who are not so high in position, feel it burden for the mental guidance in the club activities. 


\subsection{Experience Years as a Teacher and the Consciousness for Guiding the Club Activities}

3.7.1 Experience Years as a Teacher and "Want the Person to Consult With in Guiding the Club Activities"

Table 13. Experience years as a teacher and "Want the person to consult with in guiding the club activities"

\begin{tabular}{|c|c|c|c|c|c|c|c|c|}
\hline & & & \multicolumn{6}{|c|}{ 3-8 Want the person to consult with in guiding the club activities } \\
\hline & & & $\begin{array}{c}\text { Think it } \\
\text { very much }\end{array}$ & $\begin{array}{l}\text { Slightly } \\
\text { think so }\end{array}$ & $\begin{array}{c}\text { Cannot } \\
\text { say either }\end{array}$ & $\begin{array}{l}\text { Slightly do } \\
\text { not think so }\end{array}$ & $\begin{array}{c}\text { Do not think } \\
\text { so }\end{array}$ & Total \\
\hline $4-4$ & Within 1 & Frequency & 2 & 1 & 2 & 2 & 0 & 7 \\
\hline Experi & year & $\%$ & 28.6 & 14.3 & 28.6 & 28.6 & .0 & 100.0 \\
\hline ence & $1-2$ years & Frequency & 0 & 2 & 3 & 0 & 2 & 7 \\
\hline years & & $\%$ & .0 & 28.6 & 42.9 & .0 & 28.6 & 100.0 \\
\hline as a & 3-4 years & Frequency & 3 & 5 & 8 & 2 & 1 & 19 \\
\hline \multirow{5}{*}{ teacher } & & $\%$ & 15.8 & 26.3 & 42.1 & 10.5 & 5.3 & 100.0 \\
\hline & $5-9$ years & Frequency & 12 & 7 & 7 & 4 & 1 & 31 \\
\hline & & $\%$ & 38.7 & 22.6 & 22.6 & 12.9 & 3.2 & 100.0 \\
\hline & 10 years & Frequency & 12 & 22 & 34 & 12 & 19 & 99 \\
\hline & and more & $\%$ & 12.1 & 22.2 & 34.3 & 12.1 & 19.2 & 100.0 \\
\hline \multirow[t]{2}{*}{ Total } & & Frequency & 29 & 37 & 54 & 20 & 23 & 163 \\
\hline & & $\%$ & $17.8 \%$ & $22.7 \%$ & $33.1 \%$ & $12.3 \%$ & $14.1 \%$ & $100.0 \%$ \\
\hline
\end{tabular}

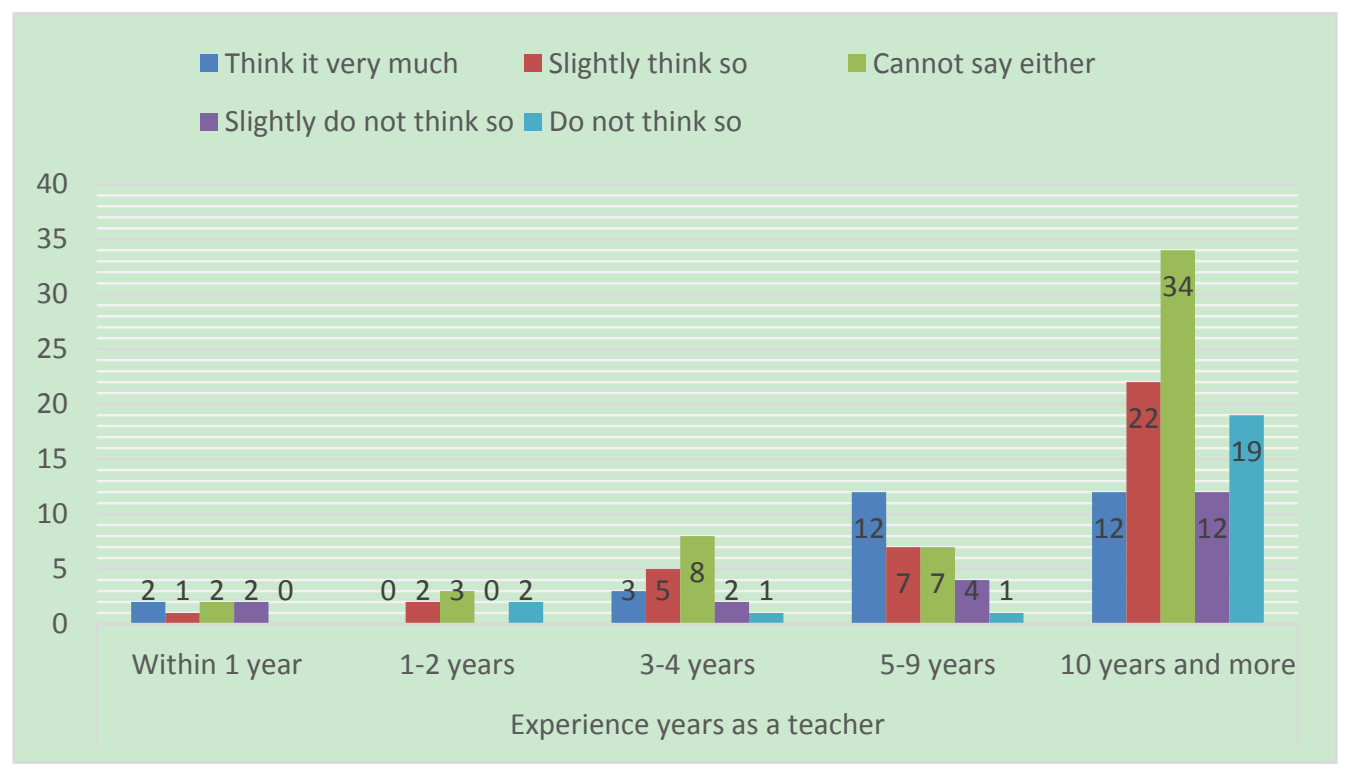

Figure 11. Experience years as a teacher and "Want the person to consult with in guiding the club activities"

Both of the teachers under experience year within 1 year and more than 5 years want the person to consult with in guiding the club activities.

\section{Remarks}

In this paper, Non-Parametric Test is applied and exquisite analysis was performed. Followings are the main results. As for Q2 "Consciousness for the daily works" and its related analysis, Null Hypotheses were rejected for 6 cases out of 60. As for Q3" Consciousness for guiding the club activities" and its related analysis, Null Hypotheses were rejected for 5 cases out of 48 .

We can observe the following themes from the analysis results.

/ Middle aged teachers maybe very busy and have a burden in many areas.

/ Female teachers may have some handicap in guiding club activities than male. 
/ Young teachers do not have enough experience in everything.

/ Rather young teachers feel it burden in mental guidance.

Thus, sex, age, position, experience as a teacher should be considered in taking measures to cope with the situation, particularly for the Null Hypotheses rejected cases, in the daily works and guiding club activities.

\section{Conclusion}

High School teachers in Japan are sending very busy days on their daily works including teaching, support for the club activities and deskwork. Among them, they share a lot of time for managing the club actives of students compared with other countries. In that area, professionals can make instruction much better than teachers for the special sports like Judo and Kendo (Japanese fencing) etc. School Social Worker can coordinate the professionals out of school and can help teachers by decreasing their burden on that area. There are few related papers concerning the support of club activities by utilizing the professionals outside. In this paper, a questionnaire investigation was executed to the five High Schools at Miyagi Prefecture in Japan in order to clarify their current condition and their consciousness, and to seek the possibility of utilizing school social worker for their support. Fundamental statistical analysis and Non-Parametric Test Analysis were performed.

In the Non-Parametric Test, followings results were obtained. As for Q2 "Consciousness for the daily works" and its related analysis, Null Hypotheses were rejected for 6 cases out of 60. As for Q3" Consciousness for guiding the club activities" and its related analysis, Null Hypotheses were rejected for 5 cases out of 48 .

We could observe the following themes from the analysis results.

/ Middle aged teachers maybe very busy and have a burden in many areas.

/ Female teachers may have some handicap in guiding club activities than male.

/ Young teachers do not have enough experience in everything.

/ Rather young teachers feel it burden in mental guidance.

Thus, sex, age, position, experience as a teacher should be considered in taking measures to cope with the situation, particularly for the Null Hypotheses rejected cases, in the daily works and guiding club activities.

Based upon the results, these suggest that unique/original approach should be executed to the "Club Activities". Teachers' burden may be decreased by utilizing outer specialist in guiding club activities. School Social Worker can coordinate the professionals out of school and can help teachers by decreasing their burden on that area. This suggests the possibility of developing the new activity field for the School Social Worker.

Various cases should be investigated here after.

\section{Acknowledgements}

The authors are grateful to all those who supported us for answering questionnaire investigation

\section{References}

Bennesse Education Research Institute. (2010). The 5th Basic Investigation Report about Instruction for Learning (High School). Retrieved from http://benesse.jp/berd/center/open/report/shidou_kihon5/kou_hon/index.html

Kelly, M.S., Berzin, S.C., Andy, M.A., Shaffer, G., \& O’Brien, K. (2010, September). The State of School Social Work: Findings from the National School Social Work Survey. School Mental Health, 2(3), 132-141. https://doi.org/10.1007/s12310-010-9034-5

Konyuba, H. (2011). Analysis on teachers' workload and development of school organization: focusing on the school club activities. National Institute for Educational Policy Research, 140, 181-193.

Yonekawa, K. (2011). The role of school social worker for mental health of a junior high school teacher. Bulletin of Faculty of Literature, Kurume University, 10·11, 7-15. 


\section{Appendix: Questionnaire about the Club Activities at High School}

\section{Q1 Please select the appropriate item in each column}

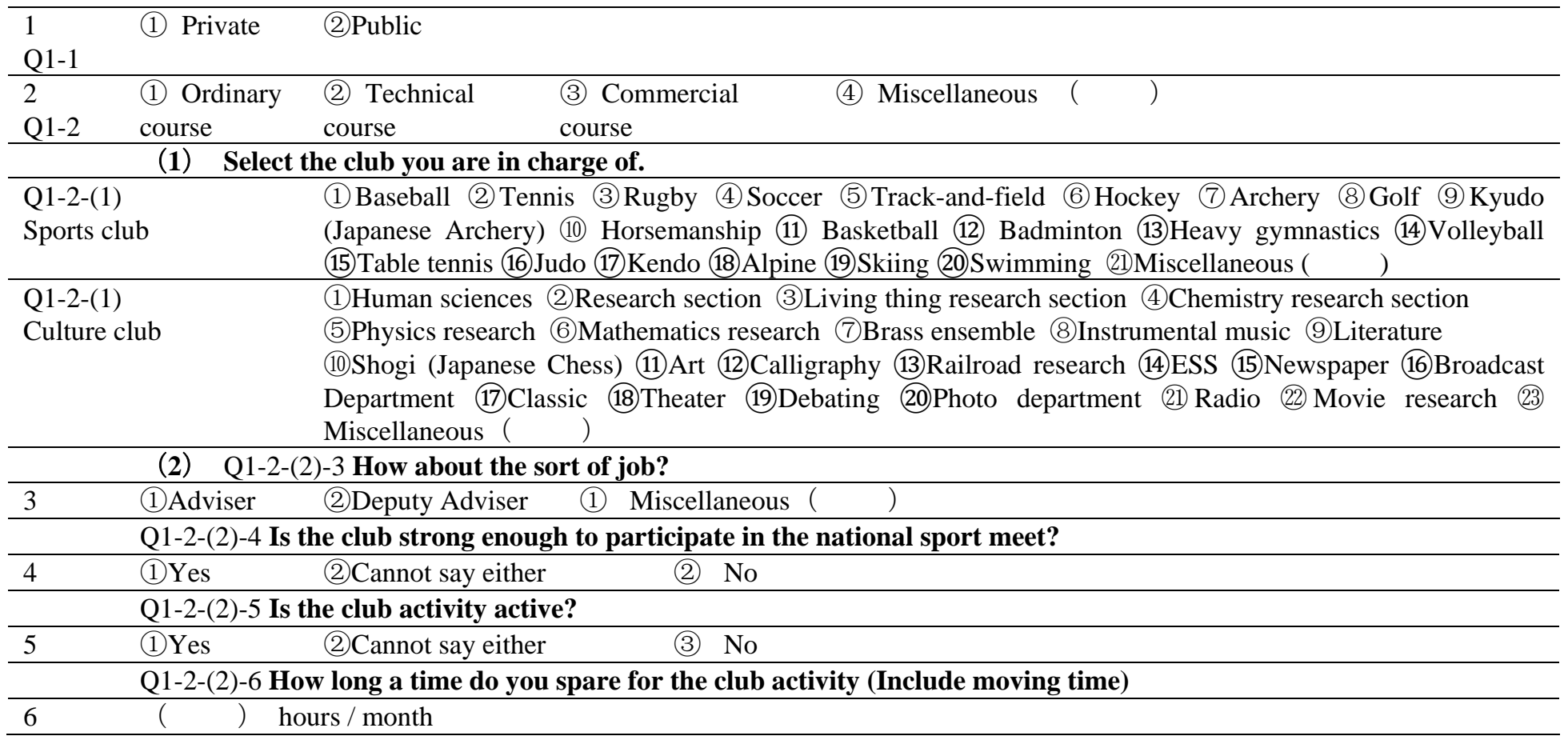

2. Q2 We ask you a consciousness for the daily works

\begin{tabular}{lllll}
\hline 1 & 2 & 3 & 4 & 5 \\
\hline Think it very much & Slightly think so & Cannot say either & Slightly do not think so & Do not think so \\
\hline
\end{tabular}

\begin{tabular}{|c|c|c|c|c|c|c|}
\hline 1. & Feel it burden to teach & 1 & 2 & 3 & & \\
\hline 2. & Feel it burden to prepare for teaching & 1 & 2 & 3 & + & 5 \\
\hline 3. & Feel it burden to instruct for learning & 1 & 2 & 3 & 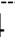 & \\
\hline 4. & Feel it burden to handle the students' performance & 1 & 2 & 3 & 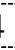 & \\
\hline 5. & Feel it burden to guide students & 1 & 2 & 3 & 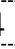 & \\
\hline 6. & Feel it burden to guide club activities & 1 & 2 & 3 & + & \\
\hline 7. & Feel it burden to attend conference & 1 & 2 & 3 & & \\
\hline 8. & Feel it burden to manage the class & 1 & 2 & 3 & & \\
\hline 9. & Feel it burden to deal with meeting, advance arrangement & 1 & 2 & 3 & & \\
\hline 10. & Feel it burden to deal with parents & 1 & 2 & 3 & & 5 \\
\hline
\end{tabular}

\section{Q3 We ask you a consciousness for guiding the club activities}

\begin{tabular}{|c|c|c|c|c|c|}
\hline 1. & Feel worthwhile to guide club activities. & 12 & 23 & 4 & 5 \\
\hline 2. & It is better for the professionals to guide club activities. & 1 & 23 & 4 & 5 \\
\hline 3. & I do not know the club field precisely that I take charge of. & 1 & 3 & 4 & 5 \\
\hline 4. & $\begin{array}{l}\text { I cannot share enough time to prepare for teaching because of the workload for } \\
\text { the guidance of club activities. }\end{array}$ & 1 & 3 & 4 & 5 \\
\hline 5. & Quite tired because of the activity on holiday. & 1 & 3 & 4 & 5 \\
\hline 6. & Have a hard time for the technical guidance. & 1 & 3 & 4 & 5 \\
\hline 7. & Have a hard time for the mental guidance. & 1 & 3 & 4 & 5 \\
\hline 8. & Want to have a person to consult with in guiding club activities. & 1 & 3 & 4 & 5 \\
\hline
\end{tabular}




\section{Q4 We ask questions about yourself}

\begin{tabular}{|c|c|c|c|c|c|c|c|c|}
\hline 1 & Sex & (1)Male & (2)Female & & & & & \\
\hline 2 & Age & (2) $20 \sim 29$ & (3) $30 \sim 39$ & (4) $40 \sim 49$ & (5) $50 \sim 59$ & $\begin{array}{l}\text { (6)More than } \\
60\end{array}$ & & \\
\hline 3 & Position & $\begin{array}{l}\text { (1) } \\
\text { Principal }\end{array}$ & $\begin{array}{l}\text { (2)Deputy } \\
\text { Principal }\end{array}$ & $\begin{array}{l}\text { (3) a person in } \\
\text { charge of } \\
\text { educational } \\
\text { affairs }\end{array}$ & (4) Teacher & (5)Lecturer & $\begin{array}{l}\text { (5) } \\
\text { Assistant }\end{array}$ & $\begin{array}{l}(7) \\
\text { Miscella } \\
\text { neous ( ) }\end{array}$ \\
\hline 4 & $\begin{array}{l}\text { Experience as a } \\
\text { teacher }\end{array}$ & $\begin{array}{l}\text { (1)Within 1 } \\
\text { year }\end{array}$ & $\begin{array}{l}\text { (2) } 1 \sim 2 \\
\text { years }\end{array}$ & (3) $3 \sim 4$ years & $\begin{array}{l}\text { (4) } 5 \sim 9 \\
\text { years }\end{array}$ & $\begin{array}{l}(5) 10 y e a r s \text { or } \\
\text { more }\end{array}$ & & \\
\hline 5 & $\begin{array}{l}\text { How many } \\
\text { years are you } \\
\text { working for the } \\
\text { present school? }\end{array}$ & $\begin{array}{l}\text { (1) Within } 1 \\
\text { year }\end{array}$ & $\begin{array}{l}\text { (2) } 1 \sim 2 \\
\text { years }\end{array}$ & (3) $3 \sim 4$ years & $\begin{array}{l}\text { (4) } 5 \sim 9 \\
\text { years }\end{array}$ & $\begin{array}{l}\text { (5) } 10 \text { years } \\
\text { or more }\end{array}$ & & \\
\hline 6 & Blood Type. & $\begin{array}{l}\text { (1) } \\
\text { A Type }\end{array}$ & (2) B Type & (3) O Type & $\begin{array}{l}\text { (4) } \mathrm{AB} \\
\text { Type }\end{array}$ & $\begin{array}{l}\text { (5) } \\
\text { Unknown }\end{array}$ & & \\
\hline 7 & $\begin{array}{ll}\text { Are } & \text { you } \\
\text { married? } & \\
\end{array}$ & (1) Single & (2)Married & & & & & \\
\hline 8 & $\begin{array}{l}\text { How many } \\
\text { children do you } \\
\text { have? }\end{array}$ & $\begin{array}{l}\text { (1) } \\
\text { Member-of } \\
\text {-society } \\
\text { (daughter } \\
\text { who got } \\
\text { married) () } \\
\text { people }\end{array}$ & $\begin{array}{l}\text { (2)College } \\
\text { student () } \\
\text { people }\end{array}$ & $\begin{array}{l}\text { (3)High school } \\
\text { student ( ) } \\
\text { people }\end{array}$ & $\begin{array}{l}\text { (4) Junior } \\
\text { high school } \\
\text { student ( ) } \\
\text { people }\end{array}$ & $\begin{array}{l}5 \\
\text { Schoolchild } \\
\text { ( ) people }\end{array}$ & $\begin{array}{l}\text { 66)ess } \\
\text { than } \\
\text { kindergar } \\
\text { ten () } \\
\text { people }\end{array}$ & $\begin{array}{l}(7) \\
\text { Nothing }\end{array}$ \\
\hline 9 & $\begin{array}{l}\text { Are you } \\
\text { positive to do } \\
\text { anything? }\end{array}$ & (3)Positive & $\begin{array}{l}\text { (2)Cannot } \\
\text { choose } \\
\text { either }\end{array}$ & (1)Not positive & & & & \\
\hline 10 & $\begin{array}{l}\text { Do you like to } \\
\text { be alone? }\end{array}$ & $\begin{array}{l}\text { (5)Think it } \\
\text { so much }\end{array}$ & $\begin{array}{l}\text { (4) Slightly } \\
\text { think it so }\end{array}$ & $\begin{array}{l}\text { (3)Cannot } \\
\text { choose either }\end{array}$ & $\begin{array}{l}\text { (2) Slightly } \\
\text { do not } \\
\text { think it so }\end{array}$ & $\begin{array}{l}\text { (1) Not think } \\
\text { it so }\end{array}$ & & \\
\hline 11 & $\begin{array}{l}\text { How do you } \\
\text { spend } \\
\text { holidays? } \\
\end{array}$ & (1) Outdoor & (2)Indoor & $\begin{array}{l}\text { (3) Cannot } \\
\text { choose either }\end{array}$ & & & & \\
\hline 12 & $\begin{array}{l}\text { What is most } \\
\text { important to } \\
\text { you? Choose } \\
\text { only one. }\end{array}$ & (1)Affection & (2)Money & (3)Honor & $\begin{array}{l}\text { (4) } \\
\text { Clothes/Eat } \\
\text { ing/House }\end{array}$ & $\begin{array}{l}\text { (5) } \\
\text { Self-realizati } \\
\text { on }\end{array}$ & $\begin{array}{l}\text { 6) } \\
\text { Miscellan } \\
\text { eous () }\end{array}$ & \\
\hline 13 & $\begin{array}{l}\text { Do you have a } \\
\text { brother? }\end{array}$ & (1)Yes & (2) No & & & & & \\
\hline \multirow[t]{3}{*}{14} & $\begin{array}{l}\text { In what } \\
\text { situation among } \\
\text { brothers? }\end{array}$ & $\begin{array}{l}\text { (1) The } \\
\text { eldest son } \\
\text { or the } \\
\text { eldest } \\
\text { daughter }\end{array}$ & $\begin{array}{l}(2) \\
\text { Between } \\
\text { (1) and (3) }\end{array}$ & $\begin{array}{l}\text { (3)Youngest } \\
\text { child }\end{array}$ & & & & \\
\hline & \multicolumn{8}{|c|}{ (1) We ask questions about your current condition. } \\
\hline & & $\begin{array}{l}\text { (5)Very } \\
\text { good }\end{array}$ & $\begin{array}{l}\text { (4)Rather } \\
\text { good }\end{array}$ & $\begin{array}{l}\text { (3) Ordinary } \\
\text { level }\end{array}$ & $\begin{array}{l}\text { (2)Not so } \\
\text { good }\end{array}$ & (1) Bad & & \\
\hline 15 & $\begin{array}{l}\text { How about your } \\
\text { physical } \\
\text { condition? }\end{array}$ & (5) & (4) & (3) & (2) & (1) & & \\
\hline 16 & $\begin{array}{l}\text { Is your work } \\
\text { progressing } \\
\text { smoothly? }\end{array}$ & (5) & (4) & (3) & (2) & (1) & & \\
\hline 17 & $\begin{array}{l}\text { Do you living a } \\
\text { full life? }\end{array}$ & (5) & (4) & (3) & (2) & (1) & & \\
\hline
\end{tabular}

